Int. J. Dev. Biol. 48: 39-46 (2004)

Original Article

\title{
Programmed cell death is not a necessary prerequisite for fusion of the fetal mouse palate
}

\author{
SACHIKO TAKAHARA ${ }^{\#, 1,3}$, TOSHIYA TAKIGAWA ${ }^{\#, 2}$ and KOHEI SHIOTA*,1,2 \\ ${ }^{1}$ Congenital Anomaly Research Center, ${ }^{2}$ Department of Anatomy and Developmental Biology, and \\ ${ }^{3}$ Department of Surgery, Kyoto University Graduate School of Medicine, Kyoto, Japan
}

\begin{abstract}
It has been widely accepted that programmed cell death (PCD) is an essential event in palatogenesis and that its failure can result in cleft palate, one of the most common birth defects in the human. However, some conflicting results have been reported concerning the timing of cell death occurring in the fusing palate and therefore the role of PCD in palatal fusion is controversial. In order to clarify whether cell death is indispensable for mammalian palatogenesis, we cultivated the palates of day-13 mouse fetuses in vitro and prevented cell death by treating them with the inhibitors of caspases- 1 and -3 or with aurintricarboxylic acid which inhibits the activity of caspaseactivated DNase. Even when cell death was almost completely inhibited, palatal fusion took place successfully. Histological examination revealed that in the absence of apoptotic cell death, the medial edge epithelia of opposing palatal shelves adhered to each other and subsequently, the midline epithelial seam was disrupted and disappeared to bring about mesenchymal confluence across the palate. It seems that cell death is not a necessary prerequisite for palatal fusion but it may help to efficiently eliminate unnecessary cells which failed to migrate or differentiate properly.
\end{abstract}

KEY WORDS: Palatal fusion, programmed cell death, apoptosis, caspase, caspase inhibitor, fetal mouse, organ culture

\section{Introduction}

The formation of the secondary palate in mammalian fetuses involves a series of developmental events that occur in a spatially and temporally coordinated manner (Ferguson, 1988; Hay, 1995; Shuler, 1995). Opposing bilateral palatal shelves elevate horizontally, grow medially and finally fuse with each other in the midline. When bilateral shelves adhere to each other, their medial edge epithelia (MEE) form the midline epithelial seam, which subsequently thins and disappears to bring about mesenchymal confluence across the palate. It is widely accepted that cell death in MEE is indispensable for adhesion and fusion of palatal shelves and that the failure of cell death to occur can result in cleft palate, one of the most common developmental defects in the human. Such cell death observed during palatal fusion has widely been documented as an example of classical programmed cell death (PCD), similarly to that seen in the interdigital tissue during digit separation (Glücksmann, 1951; Saunders, 1966; Clarke, 1990).

Morphological evidence for PCD in the fusing palate includes the presence of autophagic vacuoles, lysosomes and macrophages (Shapiro and Sweney, 1969; Smiley, 1970; Smiley and
Koch, 1972; Hinrichsen and Stevens, 1974; Ferguson 1988). However, there is disagreement as to whether MEE cell death occurs before or after the contact of palatal shelves. Cytological changes indicative of cell death such as ultrastructural changes of cell organelles, cessation of DNA synthesis and increased lysosomal levels have been observed in MEE cells prior to the contact of palatal shelves (Shapiro and Sweney, 1969; Smiley, 1970; Hudson and Shapiro, 1973; Greene and Pratt, 1976). On the other hand, using in situ labeling of DNA fragmentation, we previously detected a cytochemical evidence for apoptotic cell death occurring in the disappearing midline epithelial seam at some late stage of palatal fusion when the midline epithelial seam was disrupting, but not at earlier stages of palatogenesis (Mori et al., 1994). Recently Cuervo et al. (2002) claimed that the contact of palatal shelves is necessary for cell death activation in MEE and that cell death is a primary process required for palatal fusion.

Abbreviations used in this paper: ATA, aurintricarboxylic acid; BM, basement membrane; $\mathrm{CAD}$, caspase-activated DNase; MEE, medial edge epithelium; PCD, programmed cell death.

\footnotetext{
*Address correspondence to: Dr. Kohei Shiota, M.D. Department of Anatomy and Developmental Biology, Kyoto University Graduate School of Medicine, Kyoto 606-8501, Japan. Fax +81-75-751-7529. e-mail: shiota@anat1.med.kyoto-u.ac.jp

\# These authors contributed equally to this work.
} 
The classical hypothesis that PCD is a necessary event in palatal fusion has been challenged. Hay and her colleagues showed that the degenerating cells observed in the fusing palate are peridermal cells trapped in the midline epithelial seam but not the basal MEE cells (Fitchett and Hay, 1989) and that MEE cells never die but migrate into palatal mesenchyme to transform into mesenchymal cells (Griffith and Hay, 1992). Carette and Ferguson (1992) demonstrated that palatal MEE cells migrate orally and nasally to become incorporated into the oral and nasal epithelia, respectively, but they never detected any evidence of cell death and epithelial-mesenchymal transformation. However, Cuervo et al. (2002) recognized a large number of dying cells along the midline fusion line of the palate, in contrast to the few cells that are transformed to mesenchyme. Although Fitchett and Hay (1989) and Carette and Ferguson (1992) failed to observe cell death in the fusing palate, it surely occurs in the disappearing midline epithelial seam at some stages of palatogenesis (Mori et al., 1994; Cuervo et al., 2002). Thus, the significance of PCD in palate development remains controversial and it should be elucidated whether or not cell death is an event indispensable for palatal fusion.

PCD is morphologically known as apoptosis (Kerr et al., 1972) and it is widely accepted that apoptosis is controlled by an evolutionarily conserved genetic program which is mediated by a family of cysteine proteases called caspases (Alnemri et al., 1996). To date, at least 14 caspases have been cloned in mammals and many of them are implicated in the apoptosis process (Whyte, 1996). Mammalian cell death proteases have been divided into upstream (initiator) and downstream (effecter) caspases based on the site of action in the proteolytic caspase cascade (Numez et al., 1998). In mammals, caspases are activated by a variety of apoptotic stimuli, and the apoptotic process is largely suppressed by caspase inhibitors, suggesting that caspases are required for the execution of apoptosis (Nicholson and Thornberry, 1997).
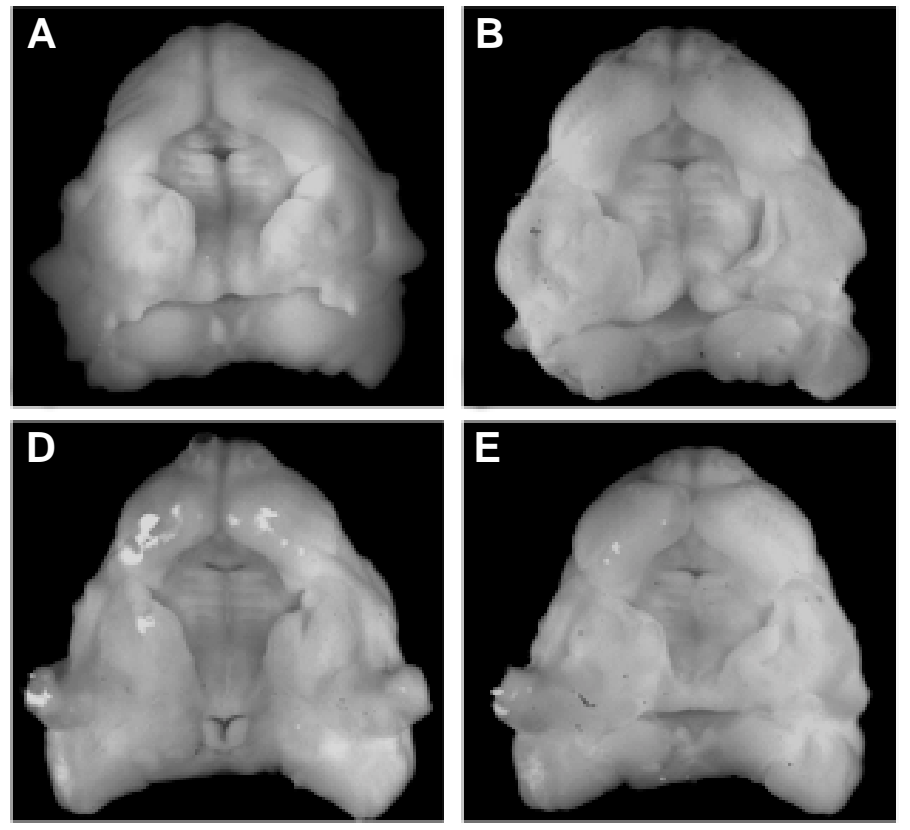

control group, and no difference een the groups. (A) Control. (B) YVAD-CHO, 10 $\mu \mathrm{M}$; (C) DEVD-CHO, $10 \mu \mathrm{M}$; (D) YVAD-CHO, $10 \mu \mathrm{M}+\mathrm{DEVD}-C H O, 10 \mu \mathrm{M}$; (E) ATA, $30 \mu \mathrm{M}$.
In the present study, we cultivated fetal mouse palates in vitro and inhibited cell death with some caspase inhibitors and with an inhibitor of caspase-activated DNase (CAD). We used the inhibitors of caspases- 1 and -3 because caspase- 1 is one of initiator caspases and caspase- 3 is among the effecter caspases. We also treated cultured palates with aurintricarboxylic acid (ATA) which inhibits the activity of CAD, a protein that causes internucleosomal degradation of chromosomal DNA (Enari et al., 1998). We designed this in vitrostudy because it is difficult to give such inhibitor proteins to pregnant animals or fetuses in uteroand because mouse embryos lacking caspase genes either die early in development or appear phenotypically normal when they are born (Kuida et al., 1995, 1996). Our results would provide a clue to understanding the significance of cell death in mammalian palatogenesis.

\section{Results}

At day 13.5, the palates of ICR mouse fetuses are usually at stage 2 or 3 of palate development (Walker and Fraser, 1956; Biddle, 1980), when palatal shelves are vertically oriented beside the tongue, except for their posterior portion which is becoming horizontal. Since the stage of palate development is variable among fetuses even within a litter, only palates at stage 2 or 3 were used for culture. When the maxillary explants of day 13.5 fetuses were cultivated in vitro, palatal shelves elevated in a couple of hours, elongated medially, and made contact with each in approximately 6 hours. In the palates cultured in the control medium, midline fusion of palatal shelves was completed by 24 hours (Fig. 1A). Thus, the process of macroscopic palatal fusion in vitro basically simulated that occurring in vivo, as observed previously (Shiota et al., 1990). Grossly, palatal fusion was observed in $92 \%$ of the palates in the control group cultured for 24 hours. In the groups treated with caspase inhibitors (YVAD-CHO

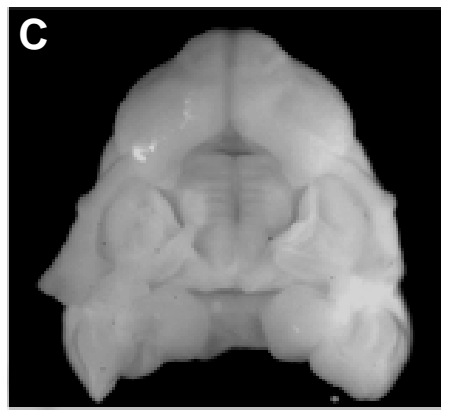
and DEVD-CHO), the rates of palatal fusion were similar to the rate in the control group (91-95\%) and no significant difference from the control group was noted in their gross appearance (Table 1, Fig. 1 B-E). The rate of palatal fusion was reduced in the group treated with $30 \mu \mathrm{M} \mathrm{ATA}(79 \%)$ as compared with controls $(P<0.01)$, which may be due to the general toxicity of ATA.

When the cultured palates were harvested, they were examined under a dissecting microscope and then subjected to histological examination. Based on gross and histological observations, the stages of palatal fusion were classified into five groups; i.e., "precontact," "contact," "adhesion," "seam disruption" and "mesenchymal confluence." At the "precontact" stage, the MEE of palatal shelves consisted of the basal 

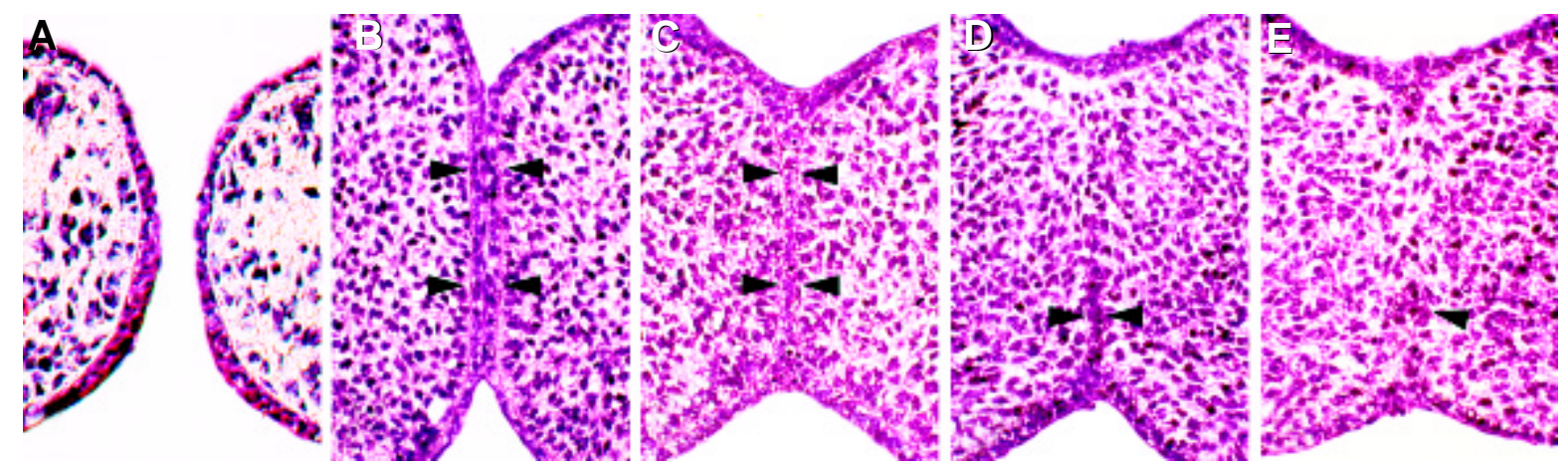

Fig. 2. Sequential stages of palatal fusion in the fetal mouse palate cultured in vitro (hematoxylin and eosin). The nasal side is shown upward. (A) "Pre-contact" stage. The medial edge epithelium consisted of tall "basal MEE" cells and thin peridemal cells. (B) "Contact" stage. The MEE cells of the opposing shelves have made contact with each other and an epithelial seam of two-cell layer thickness is formed in the midline (arrowheads). (C) "Adhesion" stage. The MEE cells of the opposing shelves have merged together to form the one cell layer thick seam (arrowheads). (D) Stage of "seamdisruption." The midline epithelial seam has lost continuity and begins to disappear (arrowheads). Some cells of the disrupted epithelial seam form epithelial islands. (E) Stage of "mesenchymal confluence." The midline epithelial seam has almost completely disappeared and mesenchymal confluence is established across the palate. A remnant epithelial island is indicated by an arrowhead.

cell layer and the superficial peridermal layer (Fig. 2A), and some peridermal cells were found to be sloughing off from the epithelial surface. At the "contact" stage, the MEE of bilateral shelves made contact with each other, thereby a seam of MEE of two cell-layer thickness was formed in the midline (Fig. 2B). At the stage of "adhesion," the major change was the thinning of the midline epithelial seam from two-cell to single-cell layer thickness by merging of the MEE cells of the opposing shelves (Fig. 2C). At this stage, some epithelial cells accumulated at the nasal and oral ends of the midline seam to form "epithelial triangles." The midline epithelial seam was continuous with the oral and nasal epithelia but still appeared to be separated from the underlying mesenchyme by the intact basement membrane (BM). At the stage of "seam-disruption," the midline epithelial seam became discontinuous and began to disappear by breaking up into epithelial islands (Fig. 2D). The mesenchymal tissue of bilateral palatal shelves became confluent where the midline epithelial seam was disrupted. Some epithelial islands of MEE cells persisted for some time in the midline of the palate. At the final stage of "mesenchymal confluence," the midline epithelial seam had almost disappeared and mesenchymal tissue was confluent across the palate (Fig. 2E). Histological examination revealed that the midline epithelial seam disappeared and mesenchymal confluence was established across the midline in most of the successfully fused control palates cultured for $24 \mathrm{hr}(51 / 52 ; 98 \%)$. In the groups treated with YVAD-CHO, DEVD-CHO or ATA, mesenchymal confluence was established in more than $80 \%$ of the grossly fused palates (Table 2). The rates of mesenchymal confluence in those groups were lower than but not significantly different from the value in the control group.

Some sections of each sample were subjected to immunohistochemical staining for cytokeratin and type IV collagen to observe the sequential changes of MEE and its BM, respectively. The sections were simultaneously stained by TUNEL for detecting apoptotic cells. At the "contact" stage, the two cell-thick midline epithelial seam was positive for both keratin and type IV collagen (Fig. $3 \mathrm{~A}, \mathrm{E}$ ), indicating that the epithelia and their BM were intact and healthy. Some MEE cells were positively stained for TUNEL. At the stage of "adhesion," the staining patterns and localization of keratin and type IV collagen were similar to those observed at the "contact" stage, and TUNEL-positive cells were detected in the epithelial seam which was one cell-thick at this stage (Fig. $3 \mathrm{~B}, \mathrm{~F}$ ). TUNEL-positive cells were recognized also in the nasal and oral epithelial triangles. At the stage of "seamdisruption," anti-cytokeratin staining showed that the midline epithelial seam is becoming discontinuous and breaking up into epithelial islands (Fig. 3 C). The BM of the midline seam had also lost continuity, and appeared to be reorganized to surround

TABLE 1

\section{MACROSCOPIC FUSION RATES IN PALATAL EXPLANTS CULTURED IN VITRO WITH OR WITHOUT APOPTOSIS INHIBITORS}

\begin{tabular}{lcccc} 
Group & No. of explants & No contact & Contact & Adhesion and fusion \\
\hline Control & 77 & $3.9 \%(3)$ & $3.9 \%(3)$ & $92.2 \%(71)$ \\
Ac-YVAD-CHO $(10 \mu \mathrm{M})$ & 84 & $3.6 \%(3)$ & $1.2 \%(1)$ & $95.2 \%(80)$ \\
Ac-DEVD-CHO $(10 \mu \mathrm{M})$ & 85 & $2.4 \%(2)$ & $2.4 \%(2)$ & $95.3 \%(81)$ \\
Ac-YVAD-CHO $(10 \mu \mathrm{M})$ & 77 & $6.5 \%(5)$ & $2.6 \%(2)$ & $90.9 \%(70)$ \\
+Ac-DEVD-CHO $(10 \mu \mathrm{M})$ & & & & \\
ATA $(30 \mu \mathrm{M})$ & 62 & $8.1 \%(5)$ & $12.9 \%(8)$ & $79.0 \%{ }^{*}(49)$ \\
\hline
\end{tabular}

( ), number of cases; * significantly different from controls $(p<0.05)$.

TABLE 2

\section{RATES OF HISTOLOGICAL FUSION (MESENCHYMAL CONFLUENCE) IN FETAL MOUSE PALATES CULTURED IN VITRO WITH OR WITHOUT APOPTOSIS INHIBITORS}

\begin{tabular}{lcc} 
Group & $\begin{array}{c}\text { No. of cases histologically } \\
\text { examined } \dagger\end{array}$ & $\begin{array}{c}\text { Rate of mesenchymal } \\
\text { confluence }\end{array}$ \\
\hline Control & 52 & $98.1 \%(51)$ \\
Ac-YVAD-CHO $(10 \mu \mathrm{M})$ & 18 & $83.3 \%(15)$ \\
Ac-DEVD-CHO $(10 \mu \mathrm{M})$ & 21 & $85.7 \%(18)$ \\
Ac-YVAD-CHO $(10 \mu \mathrm{M})$ & 20 & $80.0 \%(16)$ \\
+ Ac-DEVD-CHO $(10 \mu \mathrm{M})$ & 20 & $85.0 \%(17)$ \\
ATA $(30 \mu \mathrm{M})$ & &
\end{tabular}

† Grossly fused cases; ( ), number of cases. 


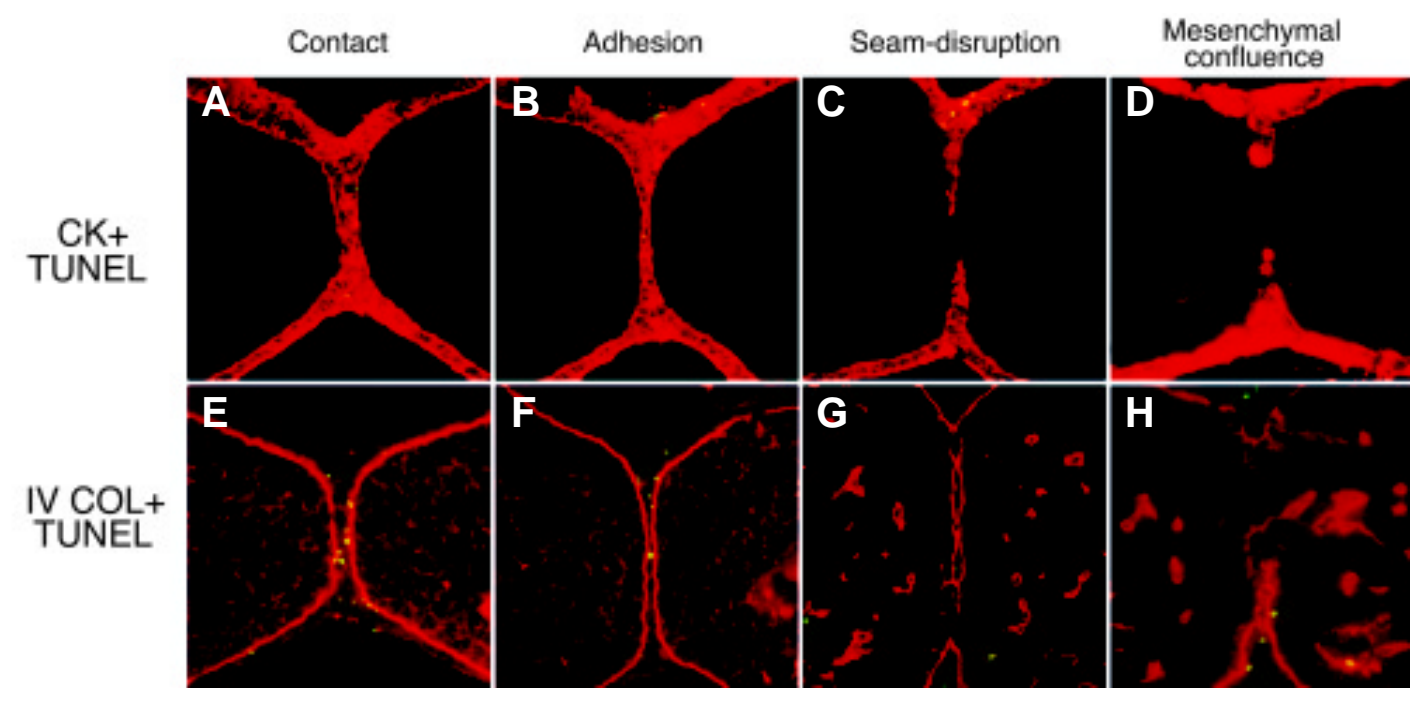

Fig. 3. Immunohistochemical stainings for epithelium and its basement membrane (BM) together with TUNEL staining for apoptotic cells in control palates cultured in vitro. (A-D) Cytokeratin (red), which is a marker for epithelia, and TUNEL staining (yellow) for dead cells. (E-H) Type IV collagen (red), which is a marker for BM, and TUNEL staining (yellow) for dead cells. As the midline epithelial seam is disrupted (C,D), its BM becomes fragmented (G) and then reorganized to form the continuous oral and nasal epithelia (H). At the stages of "contact" and "adhesion", TUNEL-positive cells are frequently observed in the MEE cells forming the midline epithelial seam and in the nasal and oral epithelial triangles $(A, B, E, F)$. At the stages of "seam disruption" and "mesenchymal confluence", TUNEL-positive cells are restricted to the epithelial triangles and some epithelial islands. The type IV collagen-positive tissues in the palatal mesenchyme in $\mathrm{G}$ and $\mathrm{H}$ are blood vessels.

epithelial islands (Fig. 3G). TUNEL-positive cells were recognized not only in epithelial islands but also in oral and nasal epithelial triangles. As mesenchymal confluence was established across the palate, TUNEL staining became restricted to the oral

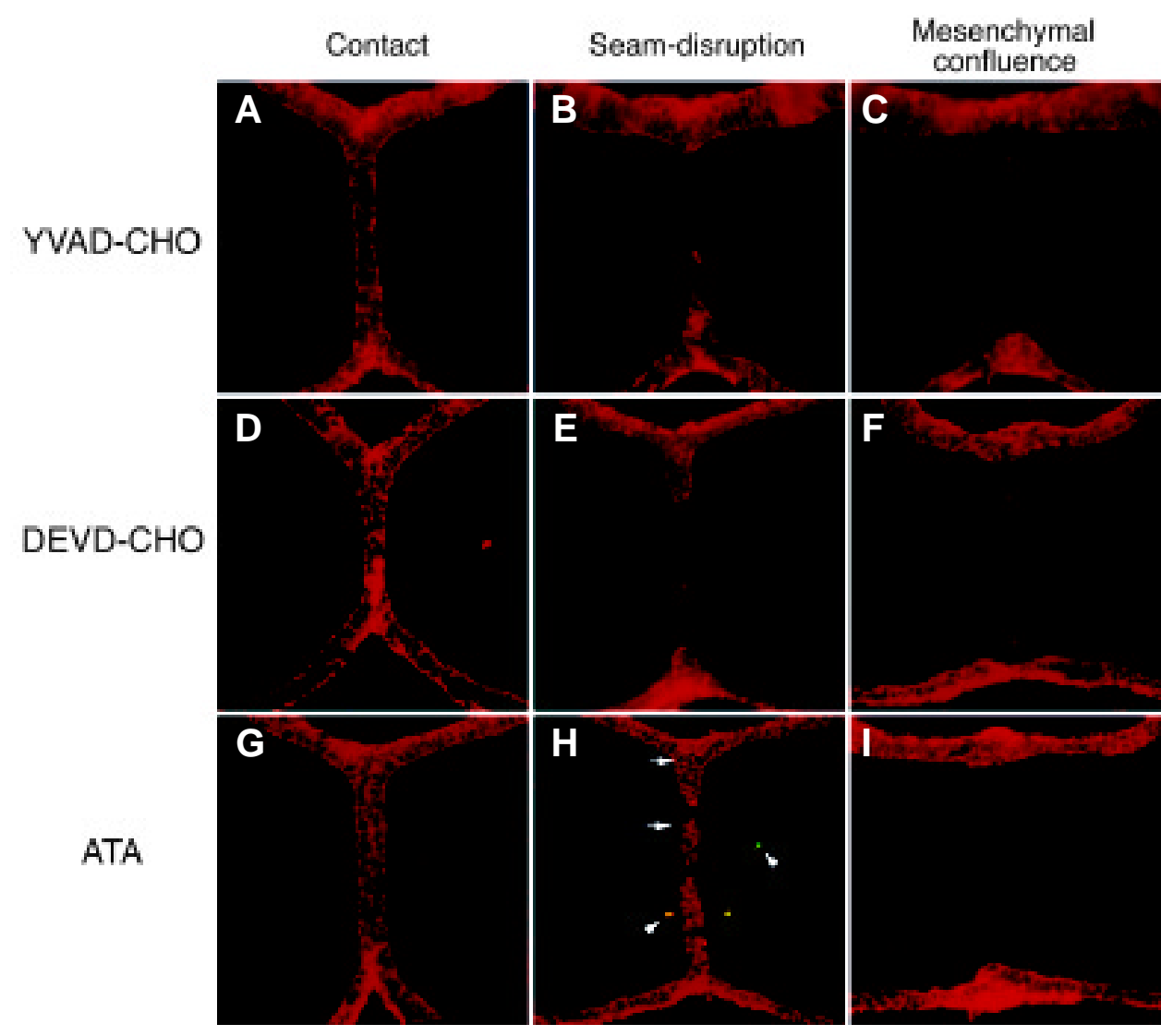

and nasal epithelial triangles (Fig. $3 \mathrm{D}, \mathrm{H}$ ). When the cells of the midline epithelial seam disappeared, the BM of the oral and nasal epithelia was reorganized to bring about the continuous nasal and oral epithelia across the palate (Fig. $3 \mathrm{H})$.

In the palates treated with YVAD$\mathrm{CHO}$ and DEVD-CHO, TUNEL staining confirmed that cell death was almost completely prevented in the explants at any stage of palatal fusion (Fig. 4 A-I). Thus, YVAD-CHO, DEVD$\mathrm{CHO}$ and ATA were shown to inhibit apoptotic cell death effectively but affected neither the gross fusion of palatal shelves nor the histological process of the disappearance of the midline epithelial seam.

The rates of TUNEL-positive cells were compared between the control and experimental groups. The rate of apoptotic cells was defined as the numbers of TUNEL-positive cells in the

Fig. 4. Double staining for cytokeratin (red) and TUNEL (yellow) of the palates cultured in vitro with YVAD-CHO, DEVDCHO or ATA. Few TUNEL-positive cells are recognized except for those in $(H)$ indicated with arrowheads. Although cell death is almost completely prevented, contact and adhesion of palatal shelves, and disruption and disappearance of the midline epithelial seam took place similarly to those observed in the control group (Fig. 3). 
MEE or in the midline epithelial seam among the total cells in the same area of MEE. In the control group, the proportions of apoptotic cells were $10.5 \pm 7.5 \%$ (mean \pm S.D.), $16.1 \pm 9.9 \%$, $11.1 \pm 8.2 \%$ and $7.9 \pm 3.5 \%$ at the stages of "contact," "adhesion," "seam disruption" and "mesenchymal confluence," respectively. In the explants treated with YVAD-CHO, DEVD$\mathrm{CHO}$ or both, the proportions of TUNEL-positive cells were between 0.2 and $0.9 \%$ throughout the stages of palatal fusion, which were significantly smaller than the corresponding values in untreated controls $(P<0.01)$. These data confirmed the effectiveness of the apoptosis inhibitors used in the present study.

\section{Discussion}

PCD has been recognized as an essential event in morphogenesis as well as in the normal turnover of cells in adult tissues (Glücksmann, 1951; Saunders, 1966; Wyllie et al., 1980; Ellis et al., 1991). When various structures are formed during development, some cells are eliminated by means of PCD to achieve complicated morphogenesis. It has been suggested that developmental PCD enables (1) sculpting body parts, (2) deleting unnecessary cells, (3) controlling cell numbers in a given tissue, (4) eliminating abnormal, misplaced or harmful cells, and (5) producing specialized differentiated cells without organelles, such as lens epithelial cells and mammalian erythrocytes (Jacobson et al., 1997). However, there are many kinds of developmental cell death whose function is unknown. Although it has been widely accepted that PCD plays essential roles in palate development, some important questions remain to be answered such as: (1) at which stage(s) of palate development PCD occurs, (2) what is the actual biological role of PCD in palatogenesis, (3) what is the fate of MEE cells that disappear from the midline epithelial seam, and (4) whether or not PCD is really required for palatal fusion.

The roles of caspases have been investigated by targeted disruption of specific caspase genes. It has been shown that targeted disruption of caspase-1 has no effect on apoptosis in vivo (Kuida et al., 1995) and that a majority of mice deficient for caspase-3 die in utero and exhibit brain malformations but no abnormalities in palate and limb development (Kuida et al., 1996). Although targeted disruption of a specific caspase can inhibit its function completely, the function may be compensated by other members of the caspase family or through alternative pathway(s). For example, at least 14 mammalian homologs of a $C$. elegans cell death gene, ced-3, have been identified to date and many of them are coexpressed in various cells and tissues (Whyte, 1996). It is likely that functional redundancy exists in the cell death pathways in complex biological systems (Kuida et al., 1996).

To investigate the roles of cell death in palatogenesis in vitro, we examined whether cell death observed in palatal MEE cells is reproducible in vitro by employing various culture methods for fetal rodent palates and compared their results. We confirmed that the suspension culture of fetal mouse palates in roller bottles (Shiota et al., 1990) was superior to static culture systems where explants were placed on Millipore filters and subjected to submerged culture. In such static cultures, nonphysiological massive cell death occurred in explants and the cultured tissues easily became necrotic (data not shown). In contrast, such non-specific cell death and necrosis were minimal in suspension organ culture (Shiota et al., 1990). Thus, the suspension organ culture of fetal mouse palates and the use of caspase inhibitors and ATA have enabled to prevent the occurrence of cell death during palatal fusion and to examine its roles in murine palatogenesis. We treated cultured palates with AcYVAD-CHO and/or Ac-DEVD-CHO, and with ATA. Ac-YVAD$\mathrm{CHO}$, a peptide inhibitor of caspases-1 and -14 was shown to inhibit the PCD in the interdigital tissues of leg buds in chick embryos (Milligan et al., 1995). Ac-DEVD-CHO is known as an inhibitor of caspases-3 (CPP32) and possibly of caspases-6, -7, -8 and -10 (Fernandes-Alnemri et al., 1995, 1996; Nicholson etal., 1995). A potent anti-apoptotic chemical ATA inhibits the interaction between DNases and chromosomal DNA, resulting in the failure of apoptosis. In our palate culture system, we confirmed that these inhibitors could efficiently prevent the cell death in MEE cells of cultured palates.

Our present study revealed that the fusion of palatal shelves could be successfully accomplished even when cell death was prevented almost completely, indicating that cell death is not indispensable for the fusion of the murine secondary palate. Histologically, even in the absence of cell death, the MEE of bilateral palatal shelves adhered to each other and the midline epithelial seam was disrupted into epithelial islands and subsequently disappeared, as observed in vivo. Many keratin-positive epithelial cells appeared to migrate toward the nasal and oral ends of the epithelial seam to form epithelial triangles. Thus, our study has clearly demonstrated that apoptotic cell death is not a necessary prerequisite for the fusion of palatal shelves nor for the disruption and disappearance of the midline epithelial seam in the mouse fetus. Although we did not examine the transformation of MEE cells into palatal mesenchymal cells, it is possible that part of MEE cells undergo epithelial-mesenchymal transformation as was shown previously (Griffith and Hay, 1992; Mori et al., 1994).

The classical hypothesis that cell death is required for palatogenesis has been proposed based on the observations as follows: (1) some MEE cells develop ultrastructural changes that are characteristic to dead cells prior to and/or during palatal fusion (Farbman,1968; Shapiro and Sweney, 1969; Chaudhry and Shah, 1973); (2) MEE cells cease DNA synthesis prior to the fusion of palatal shelves (Hudson and Shapiro, 1973; Pratt and Martin, 1975; Greene and Pratt, 1976); and (3) lysosomal enzyme levels in MEE cells increase prior to or during palatal fusion (Hayward, 1969; Smiley, 1970; Pratt and Greene, 1976). Furthermore, several morphological studies detected degenerated cells in the midline epithelial seam and among disappearing midline epithelial cells (Farbman, 1968; Hayward, 1969; Mato et al., 1972; Pratt and Hassel, 1975). However, the presence of dead cells is not a conclusive evidence of PCD in MEE cells. Fitchette and Hay (1989) undertook an ultrastructural study of the MEE of the fetal mouse palate and claimed that cell death occurs only in the superficial peridermal cells that are sloughing off or trapped in the midline but not in the basal MEE cells.

It has been shown that MEE cells cease incorporating ${ }^{3} \mathrm{H}$ labeled thymidine approximately 24 hours prior to initial contact of the opposing palatal shelves (Hudson and Shapiro, 1973; Pratt and Martin, 1975; Greene and Pratt, 1976). This phenomenon has been interpreted as a preparation of MEE cells to die. 
However, the cessation of DNA synthesis in a cell does not necessarily mean that the cell is dying. Many tissues and organs contain a population of cells which are not actively replicating but still retain the ability to resume DNA synthesis and cell division when necessary or appropriate. Therefore, the cessation of DNA synthesis in MEE cells may not necessarily be a sign of cell death. Although the intracellular increase in lysosomal enzymes has been observed in a subset of MEE cells prior to or during palatal fusion (Hayward, 1969; Smiley, 1970; Pratt and Greene, 1976), degradative enzymes may be required not only for PCD but also for epithelial-mesenchymal transformation and migration of MEE cells.

Our data strongly suggest that cell death is not an event necessary for palatal fusion, but it is surely observed at some stages of in vivo palatogenesis (Mori et al., 1994; Cuervo et al., 2002). With TUNEL staining, Mori et al. (1994) detected apoptotic cells in the disappearing midline epithelial seam and in the oral and nasal epithelial triangles at some late stages of palatal fusion. It seems that apoptosis helps eliminate some MEE cells that failed to migrate or differentiate properly during palatal fusion. Cuervo etal. (2002) showed that in the anterior palate, cell death occurred in MEE cells soon after the contact of palatal shelves when the epithelial seam was intact, but TUNEL-positive cells shown in their whole-mount samples may not be basal MEE cells in the midline epithelial seam (which cannot be seen from the surface of the palate) but the cells accumulating in the epithelial triangle along the fusion line.

Our present study using palate organ culture has clearly demonstrated that cell death is not prerequisite for mammalian palatogenesis, in contrast to the classical concept of PCD in palate development. However, this does not imply that cell death is unnecessary for palatal fusion. It is likely that apoptotic cell death contributes to efficiently eliminating some MEE cells that fail to migrate or transform properly. In this sense, the cell death observed in the midline epithelial seam of the fusing palate may not be genetically "programmed" but may be induced by some environmental cues or by the state of differentiation of the cell. It is likely that some environmental and/or intracellular signals trigger the caspase pathway and initiate the apoptotic process. It is reasonable to assume that apoptotic cell death, epithelialmesenchymal transformation, and cell migration are all involved in palatal fusion and their occurrence may be regulated in a spatially and temporally coordinated manner. This is the first report that reevaluated the significance of so-called PCD in mammalian palatogenesis, and it may be worthwhile to reexamine the roles of cell death in various developmental systems using novel experimental techniques.

\section{Materials and Methods}

\section{Animals}

Mature female mice of ICR strain (SLC, Shizuoka, Japan) were mated overnight with a male, and the day on which a vaginal plug was found was designated as day 0 of pregnancy. Between 2 and 4 p.m. on day 13, pregnant female mice were killed by cervical dislocation and the fetuses were aseptically removed from the uterus and placed in $\mathrm{BGJ}_{\mathrm{b}}$ medium (GIBCO) in a Petri dish. Palatal explants were dissected under a dissection microscope as described previously (Shiota et al., 1990). A horizontal incision was made through the oral opening, and the upper part of the head was resected by making a second incision parallel to the first incision at the level of the eyeballs. The tongue and the brain tissue were carefully removed from the explant with forceps. Special care was taken not to touch or damage the surface of the palatal shelves.

\section{Palate organ culture}

Dissected maxillary explants including palatal shelves were cultured according to the suspension culture technique developed by Shiota et al. (1990) with some modifications. Palatal explants were cultivated in a 50$\mathrm{ml}$ penicillin bottle with $8 \mathrm{ml}$ of the culture medium. The medium was BGJb (GIBCO) supplemented with $2.8 \mathrm{mg} / \mathrm{ml} \mathrm{L}$-glutamine, $6 \mathrm{mg} / \mathrm{ml} \mathrm{BSA}$ and $1 \%$ penicillin/streptomycin (Invitrogen). Three to 6 explants were put into one bottle. The bottle was flushed for approximately $2 \mathrm{~min}$ with a gas mixture of $95 \% \mathrm{O}_{2}$ and $5 \% \mathrm{CO}_{2}$, sealed air-tight, and then incubated at $37^{\circ} \mathrm{C}$ on a roller device at a speed of 20-25 rpm for up to 24 hours.

\section{Apoptosis inhibitors}

Two caspase inhibitors, Ac-YVAD-CHO (YVAD-CHO) and Ac-DEVD$\mathrm{CHO}$ (DEVD-CHO) (Takara, Kyoto, Japan), were added to the culture medium to prevent apoptosis. The tetrapeptide aldehyde YVAD-CHO (Ac-Tyr-Val-Ala-Asp-CHO) inhibits ICE/caspase-1 and caspase-14 by binding in a non-transition state conformation, while it is a very weak inhibitor to CPP32 (Thornberry et al., 1992). The tetrapeptide aldehyde Ac-DEVD-CHO (Ac-Asp-Glu-Val-Asp-CHO) contains a recognition sequence for CPP32/caspase-3 and is a potent, competitive inhibitor of this enzyme and caspases-6, -7, -8, and -10 (Alnemri et al., 1995; Nicholson et al., 1995). In addition, polymeric aurintricarboxylic acid (ATA) (Takara) was used as another inhibitor since it inhibits the activity of caspaseactivated DNase (CAD) at $30 \mathrm{mM}$ (Enari and Nagata, 1998).

To prevent cell death in explanted palates, YVAD-CHO and DEVD$\mathrm{CHO}$ were added to the culture medium at the final concentration of $10 \mu \mathrm{M}$, since these chemicals block all apoptotic events including PARP cleavage at this concentration in vitro (Lazebnik et al., 1994). ATA was added to the medium at the final concentration of $30 \mu \mathrm{M}$, which inhibits DNA degradation in most apoptotic cells (Batistatou and Green, 1993; Mogli et al., 1994).

\section{Examination of cultured palates}

After cultivation, palatal explants were immersion-fixed in 4\% paraformaldehyde buffered with $0.1 \mathrm{M}$ sodium phosphate $(\mathrm{pH} 7.4)$. They were dehydrated with ethanol and xylene, and embedded in paraffin according to standard procedures. The palatal samples were serially sectioned in a frontal plane in the thickness of $5 \mu \mathrm{m}$, mounted on slides, and stored at room temperature (RT) until further processing.

The in situ visualization of DNA fragmentation on the sections was carried out according to the method originally described by Gavrieli et al. (1992). Sections were deparaffinized in three changes of xylene, rehydrated in descending concentrations of ethanol and then immersed in double-distilled water (DDW). After rehydration, the sections were treated with $20 \mu \mathrm{g} / \mathrm{ml}$ proteinase $\mathrm{K}$ (Wako Pure Chemicals, Osaka, Japan) at $37^{\circ} \mathrm{C}$ for $10 \mathrm{~min}$ and then washed in DDW. Then the sections were immersed in TdT buffer ( $30 \mathrm{mM}$ Trizma base, $140 \mathrm{mM}$ sodium cacodylate, $1 \mathrm{mM}$ cobalt chloride) for $10 \mathrm{~min}$ at RT, and then incubated with TdT containing $12.5 \mathrm{nM}$ biotinylated-16-dUTP (Invitrogen) and $0.15 \mathrm{unit} / \mu \mathrm{l}$ TdT (Takara, Kyoto, Japan) at $37^{\circ} \mathrm{C}$ for $70 \mathrm{~min}$. The reaction was terminated by transferring the slides to TB buffer $(300 \mathrm{mM}$ sodium chloride, $30 \mathrm{mM}$ sodium citrate) for $15 \mathrm{~min}$ at RT.

After the TUNEL reaction, the same sections were incubated with $5 \%$ normal goat serum and $1 \%$ bovine serum albumin/phosphate-buffer saline (PBS) for $20 \mathrm{~min}$, and then reacted overnight at $4^{\circ} \mathrm{C}$ with a 1:4000 dilution of rabbit anti-type IV collagen antibody (LSL) or a rabbit antikeratin antibody (DAKO) as a primary antibody. After PBS wash three times, the sections were reacted with a 1:50 dilution rhodamine (RITC)conjugate goat anti-rabbit IgG second antibody (Sigma) and a 1:100 dilution fluorescein (FITC)-labelled avidin (Zymed). The slides were rinsed with PBS, coverslipped with antifade for observation under a 
fluorescence microscope. FITC and rhodamine were excited using a Zeiss microscope with fluorescein filters for fluorescence. Kodak Ektachrome films for color transparencies (ASA 400) were used for photographs.

In order to calculate the rate of TUNEL-positive cells in the MME, the slides were counterstained with Hoechst 33342 for 10 min before coverslipped with antifade. On each slide, we counted the cell number in the fusion area (fusing MEE or midline epithelial seam). The number of the total cells with Hoechst33342-stained nuclei and that of TUNEL-positive apoptotic cells were counted. A few isolated cells that appeared to be sloughing peridermal cells were not counted. Cell counts were undertaken at least on 5 slides for each stage of palatogenesis.

\section{Statistical analysis}

The rates of palatal fusion and the proportions of apoptotic cells were compared between groups by chi-square test, and statistical significance was determined at the level of $\mathrm{P}<0.05$.

\section{Acknowledgements}

We thank Dr. Shigehito Yamada for helpful discussion and technical assistance. This work was supported by Grants-in-Aid for Scientific Research from the Japanese Ministry of Education, Science, Sports, Technology and Culture and from the Japan Society for Promotion of Science.

\section{References}

ALNEMRI, E.S., LIVINGSTON, D.J., NICHOLSON, D.W., SALVESEN, G., THORNBERRY, N.A., WONG, W.W. and YUAN, J. (1996). Human ICE/CED3 protease nomenclature. Cell. 87: 171.

BATISTATOU, A. and GREENE, L.A. (1993). Internucleosomal DNA cleavage and neuronal cell survival/death. J. Cell. Biol. 122:523-532.

BIDDLE, F.G. (1980). Palate development in the mouse: a quantitative method that permits the estimation of time and rate of palate closure. Teratology. 22:239-246.

CARETTE, M.J. and FERGUSON, M.W. (1992). The fate of medial edge epithelial cells during palatal fusion in vitro: an analysis by Dil labelling and confocal microscopy. Development. 114:379-388.

CHAUDHRY, A.P. and SHAH, R.M. (1973). Palatogenesis in hamster. II. Ultrastructural observations on the closure of palate. J. Morphol. 139:329-350.

CLARKE, P.G. (1990). Developmental cell death: morphological diversity and multiple mechanisms. Anat. Embryol. (Berl) 181:195-213.

CUERVO, R., VALENCIA, C., CHANDRARATNA, R.A. and COVARRUBIAS, L. (2002). Programmed cell death is required for palate shelf fusion and is regulated by retinoic acid. Dev. Biol. 245:145-156.

ELLIS, R.E., YUAN, J.Y. and HORVITZ, H.R. (1991). Mechanisms and functions of cell death. Annu. Rev. Cell. Biol. 7:663-698.

ENARI, M., SAKAHIRA, H., YOKOYAMA, H., OKAWA, K., IWAMATSU, A. and NAGATA, S. (1998). A caspase-activated DNase that degrades DNA during apoptosis, and its inhibitor ICAD. Nature. 391:43-50.

FARBMAN, A.I. (1968). Electron microscope study of palate fusion in mouse embryos. Dev. Biol. 18:93-116.

FERGUSON, M.W.J. (1998). Palate development. Development 103s: 41-60.

FERNANDES-ALNEMRI, T., ARMSTRONG, R.C., KREBS, J., SRINIVASULA, S.M., WANG, L., BULLRICH, F., FRITZ, L.C., TRAPANI, J.A., TOMASELLI, K.J., LITWACK, G. and ALNEMRI, E.S. (1996). In vitroactivation of CPP32 and Mch3 by Mch4, a novel human apoptotic cysteine protease containing two FADD-like domains. Proc. Natt. Acad. Sci. USA. 93:7464-7469.

FERNANDES-ALNEMRI, T., LITWACK, G. and ALNEMRI, E.S. (1995). Mch2, a new member of the apoptotic Ced-3/Ice cysteine protease gene family. Cancer Res. 55:2737-2742

FITCHETT, J.E. and HAY, E.D. (1989). Medial edge epithelium transforms to mesenchyme after embryonic palatal shelves fuse. Dev. Biol. 131:455-474.

GAVRIELI, Y., SHERMAN, Y. and BEN-SASSON, S.A. (1992). Identification of programmed cell death in situ via specific labeling of nuclear DNA fragmentation. J. Cell. Biol. 119:493-501.
GLÜCKSMANN, A. (1951). Cell death in normal vartebrate ontogeny. Biol Rev 26. 59-86.

GREENE, R.M. and PRATT, R.M. (1976). Developmental aspects of secondary palate formation. J. Embryol. Exp. Morphol. 36:225-245.

GRIFFITH, C.M. and HAY, E.D. (1992). Epithelial-mesenchymal transformation during palatal fusion: carboxyfluorescein traces cells at light and electron microscopic levels. Development. 116:1087-1099.

HAY, E.D. (1995). An overview of epithelio-mesenchymal transformation. Acta Anat. (Basel) 154:8-20

HAYWARD, A.F. (1969). Ultrastructural changes in the epithelium during fusion of the palatal processes in rats. Arch. Oral. Biol. 14:661-678.

HINRICHSEN, C.F. and STEVENS, G.S. (1974). Epithelial morphology during closure of the secondary palate in the rat. Arch. Oral Biol. 19:969-980.

HUDSON, C.D. and SHAPIRO, B.L. (1973). A radioautographic study of deoxyribonucleic acid synthesis in embryonic rat palatal shelf epithelium with reference to the concept of programmed cell death. Arch. Oral Biol. 18:77-84.

JACOBSON, M.D., WEIL, M. and RAFF, M.C. (1997). Programmed cell death in animal development. Cell. 88:347-354.

KERR, J.F., WYLLIE, A.H. and CURRIE, A.R. (1972). Apoptosis: a basic biological phenomenon with wide-ranging implications in tissue kinetics. Br. J. Cancer. 26: 239-257.

KUIDA, K., LIPPKE, J.A., KU, G., HARDING, M.W., LIVINGSTON, D.J., SU, M.S. and FLAVELL, R.A. (1995). Altered cytokine export and apoptosis in mice deficient in interleukin-1 beta converting enzyme. Science. 267: 2000-2003.

KUIDA, K., ZHENG, T.S., NA, S., KUAN, C., YANG, D., KARASUYAMA, H., RAKIC P. and FLAVELL, R.A. (1996). Decreased apoptosis in the brain and premature lethality in CPP32-deficient mice. Nature. 384:368-372.

LAZEBNIK, Y.A., KAUFMANN, S.H., DESNOYERS, S., POIRIER, G.G. and EARNSHAW, W.C., (1994). Cleavage of poly(ADP-ribose) polymerase by a proteinase with properties like ICE. Nature. 371:346-347.

MATO, M., SMILEY, G.R. and DIXON, A.D. (1972). Epithelial changes in the presumptive regions of fusion during secondary palate formation. J. Dent. Res. 51:1451-1456.

MILLIGAN, C.E., PREVETTE, D., YAGINUMA,H., HOMMA, S., CARDWELL, C. FRITZ, L.C., TOMASELLI,K.J., OPPENHEIM, R.W., and SCHWARTZ, L.M. (1995). Peptide inhibitors of the ICE protease family arrest programmed cell death of motoneurons in vivo and in vitro. Neuron. 15:385-393

MOGIL, R.J., SHI, Y., BISSONNETTE, R.P., BROMLEY, P., YAMAGUCHI, I., and GREEN, D.R. (1994). Role of DNA fragmentation in T cell activation-induced apoptosis in vitro and in vivo. J. Immunol. 152.1674-1683.

MORI, C., NAKAMURA, N., OKAMOTO, Y., OSAWA, M., and SHIOTA, K. (1994). Cytochemical identification of programmed cell death in the fusing fetal mouse palate by specific labelling of DNA fragmentation. Anat. Embryol. (Berl). 190. 21-28.

NICHOLSON, D.W. and THORNBERRY, N.A. (1997). Caspases: killer proteases. Trends Biochem. Sci. 22:299-306.

NICHOLSON, D.W., ALI, A., THORNBERRY, N.A., VAILLANCOURT, J.P., DING, C.K, GALLANT, M., GAREAU, Y., GRIFFIN, P.R., LABELLE, M., LAZEBNIK, Y.A., et al. (1995). Identification and inhibition of the ICE/CED-3 protease necessary for mammalian apoptosis. Nature. 376:37-43.

NUNEZ, G., BENEDICT, M. A., HU, Y. and INOHARA, N. (1998). Caspases: the proteases of the apoptotic pathway. Oncogene. 17:3237-3245.

PRATT, R.M. and GREENE, R.M. (1976). Inhibition of palatal epithelial cell death by altered protein synthesis. Dev. Biol. 54:135-145.

PRATT, R.M. and HASSELL, J.R. (1975). Appearance and distribution of carbohydrate-rich macromolecules on the epithelial surface of the developing rat palatal shelf. Dev. Biol. 45:192-198.

PRATT, R.M. and MARTIN, G.R. (1975). Epithelial cell death and cyclic AMP increase during palatal development. Proc. Natl. Acad. Sci. USA. 72:874-877.

SAUNDERS, J.W. (1966). Death in embryonic systems. Science 154:604-612.

SHAPIRO, B.L. and SWENEY, L.R. (1969). Electron microscopic and histochemical examination of oral epithelial-mesenchymal interaction (programmed cell death). J. Dent. Res. 48:652-660. 
SHIOTA, K., KOSAZUMA, T., KLUG, S. and NEUBERT, D. (1990). Development of the fetal mouse palate in suspension organ culture. Acta. Anat. (Basel). 137: 59-64.

SHULER, C.F. (1995). Programmed cell death and cell transformation in craniofacial development. Crit. Rev. Oral. Biol. Med. 6.202-617

SMILEY, G.R. (1970). Fine structure of mouse embryonic palatal epithelium prior to and after midline fusion. Arch. Oral Biol. 15:287-296.

SMILEY, G.R. and KOCH, W.E. (1972). An in vitroand in vivostudy of single palatal processes. Anat. Rec. 173:405-416.

THORNBERRY, N.A., BULL, H.G.,CALAYCAY, J.R., CHAPMAN, K.T., HOWARD, A.D., KOSTURA, M.J., MILLER, D.K., MOLINEAUX, S.M., WEIDNER, J.R., AUNINS, J., ELLISTON, K.O., AYALA, J.M., CASANO, F.J., CHIN, J., DING, G.J.-F., EGGER, L.A., GAFFNEY, E.P., LIMJUCO, G., PALYHA, O.C., RAJU, S.M., ROLANDO, A.M., SALLEY, J.P., YAMIN, T.-T., LEE, T.D., SHIVELY, J.E., MACCROSS, M., MUMFORD, R.A., SCHMIDT, J.A. and TOCCI, M.J. (1992). A novel heterodimeric cysteine protease is required for interleukin-1 beta processing in monocytes. Nature. 356:768-774.
WALKER, B. E. and FRASER, F.C. (1956). Closure of the secondary palate in three strains of mice. J. Embryol. Exp. Morphol. 4:176-189.

WHYTE, M. (1996). ICE/CED-3 proteases in apoptosis. Trends Cel/ Biol. 6:245285.

WYLLIE, A.H., KERR, J.F. and CURRIE, A.R. (1980). Cell death: the significance of apoptosis. Int. Rev. Cytol. 68:251-306.

Received: October 2003

Reviewed by Referees: November 2003

Modified by Authors and Accepted for Publication: January 2004

Edited by: Makoto Asashima 